\title{
MENINGKATKAN KETERAMPILAN EMPATI SISWA SEKOLAH DASAR MELALUI PAKET BIMBINGAN PENINGKATAN EMPATI
}

\author{
Santy Andrianie \\ Jurusan Bimbingan dan Konseling, Universitas Nusantara PGRI Kediri \\ santyandrianie@unpkediri.ac.id \\ Restu Dwi Ariyanto \\ Jurusan Bimbingan dan Konseling, Universitas Nusantara PGRI Kediri \\ restudwiariyanto@unpkediri.ac.id \\ Rosalia Dewi Nawantara \\ Jurusan Bimbingan dan Konseling, Universitas Nusantara PGRI Kediri \\ rosaliadewi@unpkediri.ac.id
}

\begin{abstract}
Abstrak
Hasil survei LSM Plan International dan International Centre for Research on Women (ICRW) yang dirilis awal Maret 2015 menunjukkan fakta bahwa 84\% anak di Indonesia mengalami kekerasan di sekolah. Penanganan perilaku bullying tidak akan efektif jika tidak dibarengi dengan upaya prefentif. Masih minimnya upaya dan media pencegahan perilaku bullying menjadi permasalahan yang perlu mendapatkan penyelesaian agar cita-cita mewujudkan generasi yang berkarakter dapat terwujud. Individu pelaku kekerasan yang merujuk pada bullying memiliki kemampuan empati yang rendah serta tingkat agresivitas tinggi, sehingga melatih empati dapat digunakan sebagai upaya pencegahan perilaku agresif yang merujuk pada bullying.

Penelitian ini bertujuan untuk mengetahui keefektifan paket bimbingan peningkatan empati berbasis experiential learning dalam meningkatkan keterampilan empati siswa sekolah dasar. Penelitian ini berjenis eksperimen kuasi dimana terdapat kelompok eksperimen yang akan diberikan treatmen berupa penerapan paket bimbingan peningkatan empati berbasis experiential learning dan kelompok kontrol yang akan diberikan materi empati secara ekspositori. Penelitian dilakukan di SDN Bulu Purwoasr. Subyek yang digunakan adalah siswa kelas $\mathrm{V}$ sesuai dengan karakteristik paket bimbingan peningkatan empati yang berjumlah 32 siswa untuk kemudian dikelompokkan secara acak ke dalam kelompok eksperimen dan kelompok kontrol. Kelompok kontrol akan mendapatkan treatmen empati menggunakan metode klasikal sedangkan kelompok eksperimen akan mendapatkan treatmen menggunakan paket bimbingan peningkatan empati berbasis experiential learning. Masing-masing akan mendapatkan treatmen sebanyak empat kali dengan durasi 35 menit setiap sesinya. Keterampilan empati diukur dengan menggunakan skala empati yang dikembangkan oleh M.H Davis yaitu Interpersonal Reactivity Index (IRI) yang telah disesuaikan dengan bahasa anak-anak Indonesia serta telah melalui uji ahli, uji validitas, dan reliabilitas.

Berdasarkan hasil analisis data, berdasarkan skor Uji independen $\mathrm{T}$, terdapat perbedaan keterampilan empati yang dimiliki kedua kelompok baik sebelum maupun sesudah pemberian perlakuan. Hal ini ditunjukkan dari skor uji independent $\mathrm{T}$ keduanya baik sebelum maupun setelah perlakuan, memiliki skor 0,37 dan 0,02 atau kurang dari 0,05 yang merupakan ambang batas skor signifikansi uji T. Pada kegiatan postest, kelompok kontrol memiliki skor mean yang lebih tinggi dibandingkan dengan kelompok eksperimen, yaitu 64,1:62,9. Namun setelah diberikannya perlakuan, skor mean kelompok kontrol lebih rendah dibandingkan kelompok eksperimen yaitu 76,5:79,1. Selisih persentase kenaikan dari pretest ke postest juga lebih besar kelompok ekperimen dengan 16,2\% dari pada kelompok kontrol dengan $12,4 \%$. Sumbangan efektif dari penggunaan paket bimbingan peningkatan empati berbasis experiential learning adalah $25,8 \%-19,5 \%=6,3 \%$. Dapat disimpulkan bahwa Ini artinya paket bimbingan peningkatan empati berbasis experiential learning efektif untuk diterapkan pada siswa kelas V sekolah dasar.

Kata Kunci: Peningkatan Empati, Siswa Sekolah Dasar, Paket Bimbingan Peningkatan Empati
\end{abstract}




\begin{abstract}
The results of a survey by Plan International and International Center for Research on Women (ICRW) survey released in early March 2015 show that $84 \%$ of children in Indonesia are experiencing violence in schools. Handling bullying behavior will not be effective if not accompanied by a prefentive effort. The lack of efforts and media prevention of bullying behavior becomes a problem that needs to get a settlement in order to realize the ideals of a character that can be realized. Individual abusers who refer to bullying have low empathy skills and high aggressiveness, so training empathy can be used as an effort to prevent aggressive behavior that refers to bullying.

This study aims to determine the effectiveness of empathy based guidance package based on experiential learning in improving the empathy skills of elementary school students. This research is a type of quasi experiment in which there are experimental groups that will be given treatments in the form of application of empathy based guidance counseling based on experiential learning and control group which will be given empathy material expository. The research was conducted at SDN Bulu Purwoasr. The subjects used were class V students according to the characteristics of the empathy improvement guidance package, which amounted to 32 students and then grouped randomly into the experimental group and the control group. The control group will receive empathic treatments using classical methods while the experimental group will get treatments using empathy based empathy guidance package based on experiential learning. Each will get four treatments with a duration of 35 minutes each session. Empathic skills are measured using the empathy scale developed by M.H Davis, the Interpersonal Reactivity Index (IRI) that has been adapted to Indonesian children's language and has been through expert test, validity test, and reliability.

Based on the results of data analysis, based on Independent T test scores, there are differences in empathy skills possessed by both groups both before and after treatment. It is shown from the score of the independent $\mathrm{T}$ test both before and after treatment, has a score of 0.37 and 0.02 or less than 0.05 which is the threshold of the significance score of the $\mathrm{T}$ test. In the postest activity, the control group has a mean more score high compared with the experimental group, ie 64.1: 62.9. However, after the treatment was given, the mean score of the control group was lower than the experimental group of 76.5: 79.1. The difference in percentage increase from pretest to posttest was also greater in the experimental group with $16.2 \%$ than in the control group with $12.4 \%$. The effective contribution of the use of empathy based experiential learning guidance package is $25.8 \%-19.5 \%=6.3 \%$. It can be concluded that This means that the guidance package of empathy improvement based on experiential learning is effective to be applied to grade $\mathrm{V}$ elementary school students.
\end{abstract}

Keywords: Empathy Improvement, Elementary School Students, Empathy Improvement Guidance Package

\section{PENDAHULUAN}

Fenomena kekerasan di sekolah yang dilakukan oleh teman sebaya di Indonesia semakin meningkat. Berdasarkan hasil survei yang dilakukan oleh LSM Plan International dan International Centre for Research on Women (ICRW) yang dirilis awal Maret 2015 menunjukkan fakta bahwa $84 \%$ anak di Indonesia mengalami kekerasan di sekolah. Angka ini lebih tinggi dari tren kawasan Asia yang berkisar pada angka 70\%.

Fenomena kekerasan di sekolah dasar juga ditemukan dalam proses pengamatan fenomena lapangan yang dilakukan pada tahun 2015 saat proses penulisan tesis yang berjudul Pengembangan Paket Bimbingan Berbasis Experiential learning untuk Meningkatkan Empati Siswa Sekolah Dasar oleh Santy Andrianie (2015). Pemotretan fenomena lapangan dilakukan di Sekolah Dasar Bulu, Purwoasri, Kediri. Berdasarkan wawancara yang peneliti lakukan kepada pengawas sekolah dasar di SDN Bulu Purwoasri yang diperkuat oleh kepala sekolah dan guru pada 2 Oktober 2015, kekerasan yang terjadi di sana berupa mengolok-olok, memukul, mengintimidasi, dan menodong/premanisme terjadi di sekolah ini. Peristiwa bullying ini telah berlangsung lama dan terstruktur dimana pelaku bullying dulunya adalah korban bullying. Hal ini sesuai dengan teori bullying yang disampaikan Coroloso (2008) yang menjelaskan bahwa bullying merupakan sebuah mata rantai dimana korbannya sangat mungkin menjadi pelaku bullying sebagai bentuk eksistensi diri dan rasa ingin balas dendam.

Penelitian Saripah (2010) menunjukkan bahwa individu pelaku kekerasan yang merujuk pada bullying memiliki kemampuan empati yang rendah serta tingkat agresivitas tinggi. Mereka senang melihat orang lain kesusahan atau menderita, di sisi lain mereka tidak menunjukkan rasa bersalah ketika melakukan tindakan bullying baik berupa fisik maupun verbal.

Menurut Borba (2008) empati merupakan kemampuan memahami perasaan dan kekhawatiran orang lain. Dengan empati anak dapat memahami, merasakan, menghayati orang lain karena dalam proses empati ini berlangsung proses pengertian dan perasaan yang dinyatakan bentuk hubungan antar pribadi. Keterampilan empati yang baik akan membantu anak untuk mampu mengendalikan perilakunya yang mengarah pada kekerasan. Berdasarkan hal ini, sekolah dapat mencegah kekerasan yang terjadi disekolah dengan meningkatkan empati pada diri siswa.

Experiential learning merupakan model pembelajaran yang menekankan pada aktifitas mengalami, merefleksikan dan melakukan tindakan, sehingga dari pemahaman dan pengalaman selama proses belajar akan membentuk suatu pemahaman baru. Seorang siswa dikatakan berhasil setelah mendapatkan pelatihan melalui model ini apabila siswa tersebut a) mampu mendapatkan pengalaman secara langsung, b) mampu merefleksikan pengalaman yang diperoleh secara langsung, c) mampu mengkonsepualisasikan pengalaman yang diperoleh 
secara tepat sehingga memperoleh sebuah konsep yang baru, d) mampu menerapkan konsep baru yang diperoleh dalam kehidupan nyata.

Model pembelajaran experiential learning dianggap tepat untuk meningkatkan empati pada siswa. Hal ini didasarkan pada konsep model ini yang tidak hanya menginterfensi ranah kognitif namun juga ranah afektif. Kedua ranah ini akan berpengaruh dalam tindakan sosial atau perilaku individu. Pemahaman dan kesadaran diperlukan untuk pertimbangan individu melakukan suatu tindakan yang efektif di lingkungan sosial. Oleh karena itu, pemilihan model intervensi yang tepat akan memberikan stimulus yang tepat dalam mengembangkan kedua aspek tersebut. Metode ini membuat anak menjadi peka terhadap kebutuhan dan perasaan orang lain, mendorong anak menolong orang yang kesusahan atau kesakitan, serta menuntut anak untuk memperlakukan orang dengan kasih sayang. Meningkatnya keterampilan empati pada siswa diharapkan dapat mencegah tindak kekerasan atau perilaku bullying siswa.

Dari penjelasan yang telah dijelaskan tersebut, dapat disimpulkan bahwa kekerasan di sekolah dasar saat ini perlu segera mendapat penyelesaian. Menurut hasil penelitian, seorang pelaku kekerasan memiliki tingkat empati yang rendah. Experiential learning merupakan suatu model pembelajaran yang tahapannya sesuai untuk mengajarkan suatu keterampilan sosial. Berdasarkan alasan-alasan tersebut, peneliti tertarik untuk melakukan penelitian penerapan paket bimbingan peningkatan empati berbasis experiential learning bagi siswa sekolah dasar sebagai jawaban dari permasalahan bullying yang ada di sekolah sebagai upaya preventif.

\section{METODE}

Penelitian ini menggunakan pendekatan kuantitatif. Penelitian dengan pendekatan kuantitatif menekankan pada data berupa angka yang pengolahan datanya dilakukan dengan metode statistik. Dalam konteks penelitian ini, pendekatan kuantitatif ditujukan untuk mengetahui perubahan antara sebelum dilakukannya intervensi dan setelah dilakukan intervensi dan membandingkan keterampilan empati siswa yang mendapatkan intervensi berupa paket bimbingan peningkatan empati berbasis experiential learning dan siswa yang mendapatkan materi empati melalui metode ekspositori.

Sesuai dengan permasalahan yang diteliti, guna menguji efektivitas paket bimbingan peningkatan empati berbasis experiential learning bagi siswa sekolah dasar, maka penelitian dilakukan menggunakan desain eksperimental dengan membandingkan dua kelompok dimana peneliti menguji apakah suatu aktivitas atau materi menghasilkan perbedaan diantara kelompok partisipan penelitian. Metode yang dipilih adalah metode eksperimen kuasi, dimana tidak dilakukan penugasan random melainkan pengelompokan kelompok berdasarkan kelompok yang terbentuk sebelumnya.
Dalam desain ini, peneliti memilih kelompok ekperimen dan kelompok kontrol, kemudian dua kelompok yang ada di beri pretest yang sama. Setelah dilakukan pretest, kelompok eksperimen akan diberikan intervensi berupa penerapan paket bimbingan peningkatan empati berbasis experiential learning, sementara kelompok kontrol akan diberikan intervensi berupa materi empati yang akan diberikan secara ekspositori. Setelah pemberian intervensi selesai, maka kedua kelompok akan diberikan posttest. Desain ini dipilih karena peneliti dapat memanipulasi variabel bebas sesuai dengan kebutuhan penelitian dan membedakan kelompok yang mendapatkan intervensi dan yang tidak mendapatkan intervensi.

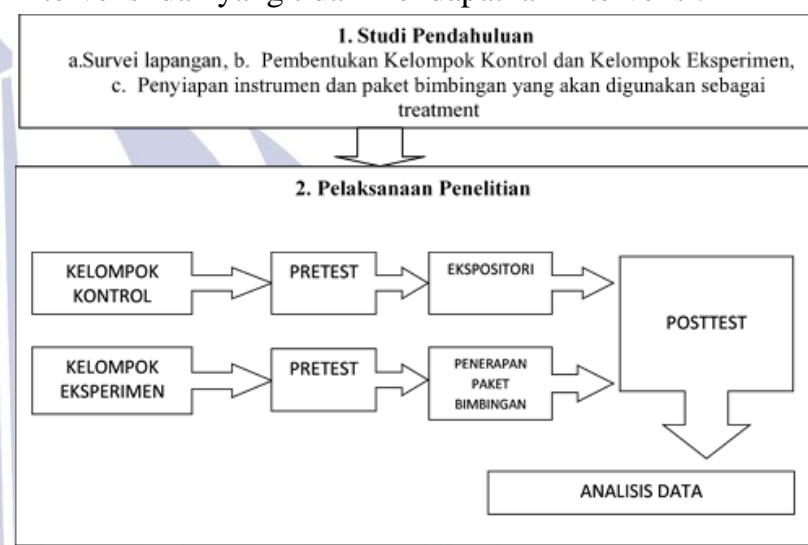

\section{Gambar. Rancangan Penelitian}

Penelitian ini dilaksanakan SD Negeri Bulu, kecamatan Purwoasri, Kabupaten Kediri, Provinsi Jawa Timur. Alasan pemilihan SD Negeri Bulu sebagai lokasi penelitian karena di sekolah ini terdapat peristiwa bullying pada siswa. Selain itu, sekolah ini juga menjadi lokasi yang melatarbelakangi dikembangkannya paket bimbingan peningkatan empati berbasis experiential learning. subyek dan sampel dalam penelitian ini adalah seluruh siswa kelas V di SDN Bulu Purwoasri. Pemilihan subyek penelitian sesuai dengan karakteristik pengguna paket bimbingan peningkatan empati yang ditujukan untuk siswa kelas V. Dari jumlah siswa kelas V di lokasi tersebut sebanyak 32 anak, kesemuanya dijadikan sebagai sampel dengan membagi sampel ke dalam dua kelompok yakni kelompok kontrol dan kelompok eksperimen secara acak sesuai dengan tujuan penelitian untuk mengetahui adanya perbedaan peningkatan keterampilan empati tretmen yang akan diberikan.

Instrumen yang digunakan dalam penelitian ini adalah skala empati siswa yang dikembangkan berdasarkan skala empati yang dikembangkan oleh M.H Davis yaitu Interpersonal Reactivity Index (IRI) yang disesusikan dengan bahasa yang mudah dipahami anak-anak. Dari 28 butir yang ada pada IRI kemudian diterjemahkan dan disesuaikan dengan bahasa anak. Instrumen ini telah melalui uji ahli bahasa, ahli pendidikan dasar, dan ahli bimbingan dan konseling untuk kemudian dilakukan 
validasi dan realibilitas sehingga tersisa 25 butir yang layak dan kemudian digunakan sebagai instrumen pretest dan postest yang menyertai paket bimbingan empati berbasis experiential learning. Data angka didapatkan dari hasil pelancaran pretest yang diberikan kepada kelompok eksperimen dan kelompok kontrol untuk mengetahui posisi awal tingkat keterampilan empati siswa. Data angka juga didapatkan dari hasil postest yang diberikan kepada kelompok kontrol dan kelompok eksperimen setelah diberikannya perlakuan. Teknik analisis data yang digunakan adalah dengan menggunakan uji independent.

\section{HASIL DAN PEMBAHASAN}

Pada kegiatan studi pendahuluan, masih ditemui adanya perilaku kurang empati dikalangan siswa, baik antar siswa maupun siswa dengan warga sekolah lainnya. Beberapa perilaku kurang empati yang tampak dilakukan oleh siswa seperti masih adanya saling olok nama antar siswa, masih masih ada siswa laki-laki yang saling pukul saat bertengkar, menertawakan teman yang terjatuh, dan masih ada ucapan intimidasi antar siswa. Selain itu, siswa tampak tidak memperdulikan himbauan guru untuk tertib di kelas selain itu saat guru kesulitan membawa barangbarangnya, siswa tampak acuh dan tidak membantu. Beberapa siswa juga tampak membuang sampah sembarangan saat tukang kebun sekolah baru saja membersihkan halaman. Perilaku-perilaku tersebut masih sering terlihat di sekolah, sementara tindakan yang diambil oleh guru adalah dengan menegur secara lisan. Apabila perkelahian terjadi sampai mengakibatkan ada yang terluka, pihak sekolah biasanya memanggil orangtua kedua belah pihak untuk dapat menyelesaikan masalah tersebut secara kekeluargaan.

Tahapan inti penelitian ini dilaksanakan di kelas $\mathrm{V}$ sebagai subyek penelitian yang sesuai dengan paket bimbingan peningkatan empati berbasis experiential learning yang akan digunakan. Siswa kelas V yang berjumlah 34 siswa kemudian dibagi menjadi dua kelompok yaitu kelompok eksperimen yang akan diberikan perlakuan dengan menerapkan paket bimbingan peningkatan empati berbasis experiential learning, dan kelompok kontrol yang akan diberi materi empati secara klasikal. Kedua kelompok ini sama-sama akan diberikan empat kali treatmen dimana siswa akan diberikan pretes dan postes di awal dan akhir kegiatan penelitian. Skor pretes dan postes dari masing-masing kelompok kemudian akan dibandingkan untuk mengetahui efektifitas penerapan paket bimbingan peningkatan empati berbasis eksperiential learning.

Selama kegiatan penelitian, seluruh kegiatan penelitian pada dua kelompok dapat terlaksana dengan lancar dan baik. Siswa tampak dapat mengikuti segala kegiatan dengan penuh perhatian dan semangat. Namun demikian, pada kelompok eksperimen masih ada beberapa kegiatan yang perlu persiapan yang cukup panjang seperti kegiatan bermain peran dan pengamatan. Pada kegiatan bermain peran, siswa sekolah dasar masih belum pernah mengalaminya sehingga perlu penjelasan dan motivasi lebih pada siswa. Pada saat bermain peran, siswa masih tampak malu-malu memulainya. Meskipun demikian kegiatan bermain peran dapat berjalan dengan lancar. Sementara pada kegiatan pengamatan ekspresi wajah di sekitar siswa, beberapa siswa tampak malu-malu saat tahu ia sedang diamati, sehingga ekspresi yang ditunjukkan terkesan dibuat-buat. Sementara pada kelompok kontrol tidak terjadi kendala yang berarti.

Kegiatan analisis data dilaksanakan dengan mentabulasi skor pretes dan postes dari kelompok eksperimen dan kelompok kontrol. Kedua skor tersebut kemudian diolah dan dibandingkan untuk mengetahui efektifitas penggunaan paket bimbingan peningkatan empati berbasis experiential learning bagi siswa sekolah dasar. Sampai saat ini, tim peneliti masih dalam tahap pentabulasian dan pengolahan data sehingga belum didapatkan hasil akhir perbandingan dari penerapan dua metode tersebut.

Uji yang digunakan adalah uji independent $\mathrm{T}$ tes. Uji ini bertujuan untuk mengetahui adanya perbedaan ketrampilan empati yang pada kedua kelompok penelitian baik sebelum maupun sesudah mendapatkan perlakuan. Adapun hasilnya adalah sebagai berikut:

\section{Tabel Uji Independent T Test Pretest}

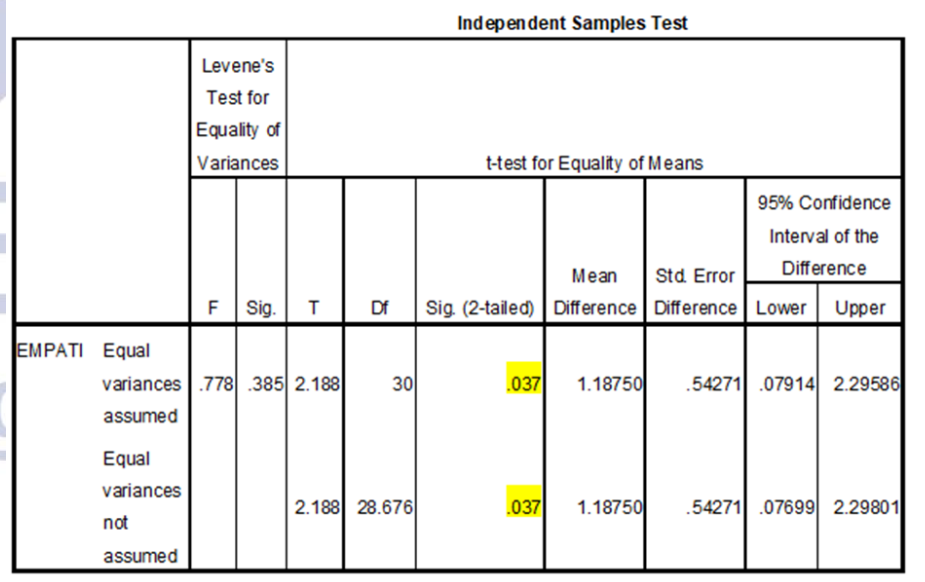


Tabel Uji Independent T test Postest

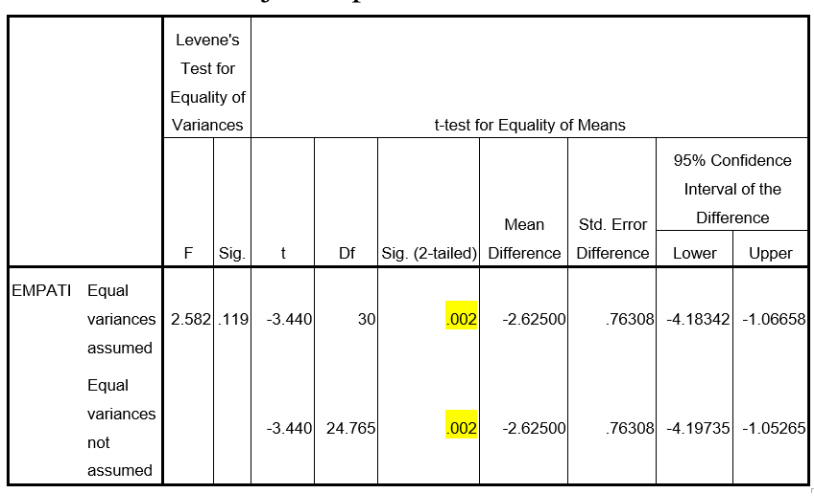

Berdasarkan skor di atas, terdapat perbedaan keterampilan empati yang dimiliki kedua kelompok baik sebelum maupun sesudah pemberian perlakuan. Hal ini ditunjukkan dari skor uji independent $\mathrm{T}$ keduanya baik sebelum maupun setelah perlakuan, memiliki skor kurang dari 0,05 yang merupakan ambang batas skor signifikansi uji T.

\section{a.) Deskripsi Data}

Keseluruhan hasil tes kemudian diakumulasikan dan dianalisis untuk selanjutnya disajikan dalam deskripsi data sebagai berikut:

\section{Tabel Deskripsi Data Pretest}

\begin{tabular}{|ll|r|c|r|r|}
\hline \multicolumn{7}{|c|}{ Group Statistics } \\
\hline EMPATI & KELAS & N & Mean & Std. Deviation & Std. Error Mean \\
& KONTROL & 16 & 64.1250 & 1.36015 & .34004 \\
& EKSPERIMEN & 16 & 62.9375 & 1.69189 & .42297 \\
\hline
\end{tabular}

Table Deskripsi Data Postest

\begin{tabular}{|ll|r|r|r|r|}
\hline \multicolumn{1}{|c|}{ Group Statistics } \\
\hline EMPATI & KONAS & \multicolumn{1}{c|}{$\mathrm{N}$} & \multicolumn{1}{c|}{ Mean } & Std. Deviation & Std. Error Mean \\
& EONTOL & 16 & 76.5000 & 2.60768 & .65192 \\
& EKSPERIMEN & 16 & 79.1250 & 1.58640 & .39660 \\
\hline
\end{tabular}

Berdasarkan paparan deskripsi data di atas, dapat disimpulkan bagwa jumlah sampel pada kegiatan pretest dan postest dama yaitu 32 siswa yang terbagi menjadi dua kelompok, yaitu kelompok kontrol dan eksperimen yang masing-masing beranggotangan 16 siswa. pada kegiatan postes, kelompok kontrol memiliki skor mean yang lebih tinggi dibandingkan dengan kelompok eksperimen, yaitu 64,1:62,9. Namun setelah diberikannya perlakuan, skor mean kelompok kontrol lebih rendah dibandingkan kelompok eksperimen yaitu 76,5:79,1.

Tabel Tabulasi Pretest Postest Kelompok Kontrol dan Eksperimen

\begin{tabular}{|c|c|c|c|c|c|}
\hline No. & Kelompok & Pretest & Postest & Selisih & Persentase \\
\hline 1 & Kontrol & 64,1 & 76,5 & 12,4 & 19,5 \\
\hline 2 & Eksperimen & 62,9 & 79,1 & 16,2 & 25,8 \\
\hline
\end{tabular}

Berdasarkan tabel di atas, dapat disimpulkan bahwa bimbingan menggunakan paket bimbingan peningkatan empati berbasis experiential learning dapat meningkatkan perilaku empati siswa kelas V sekolah dasar. Selisih persentase kenaikan dari pretest ke postest juga lebih besar kelompok ekperimen dengan 16,2\% dari pada kelompok kontrol dengan $12,4 \%$. Sumbangan efektif dari penggunaan paket bimbingan peningkatan empati berbasis experiential learning adalah $25,8 \%-19,5 \%=6,3 \%$

Berdasarkan analisis di atas, maka dapat disimpulkan bahwa paket bimbingan peningkatan empati berbasis experiential learning dapat diterapkan pada siswa kelas $\mathrm{V}$ sekolah dasar dan efektif untuk meningkatkan keterampilan empati siswa. paket bimbingan peningkatan empati berbasis experiential learning ini dibuat sebagai upaya untuk menekan perilaku agresif dan bullying yang kian marak di kalangan remaja. Dengan terbentuknya karakter empati dapa diri seseorang, maka perilaku agresif yang memicu timbulnya perilaku bullying dapat ditekan.

Paket bimbingan peningkatan empati berbasis experiential learning ini ditujukan untuk digunakan siswa kelas V sekolah dasar. Dalam pengembangannya, paket bimbingan ini disesuaikan dengan tahap belajar siswa kelas V sekolah dasar serta mempertimbangkan berbagai aspek sesuai dengan tahap perkembangan siswa kelas $\mathrm{V}$ sekolah dasar seperti kemudahan, kemenarikan, dan kesesuaian media dengan usia anak. Adanya paket bimbingan ini diharapkan mampu menjadi salah satu media bimbingan yang dapat di terapkan di jenjang sekolah dasar, mengingat belum tersedianya guru bimbingan dan konseling di jenjang sekolah dasar. Selain itu, dalam pengembangannya pengembang juga memperhatikan aspek kemudahan penggunaan dimana nantinya pelaksananya adalah guru kelas yang belum memiliki dasar-dasar bimbingan maupun belum pernah mengikuti pelatihan bimbingan bagi siswa sekolah dasar. Dalam penelitian ini, peneliti mendampingi secara penuh baik selama simulasi maupun pelaksanaan layanan bimbingan dengan menggunakan paket bimbingan peningkatan empati berbasis experiential learning yang dilaksanakan oleh guru. Hal ini bertujuan untuk menjamin keterlaksanaan kegiatan bimbingan sebagaimana mestinya sehingga hasil penelitian dapat valid.

Paket bimbingan peningkatan empati berbasis experiential learning memiliki empat bagian yang menyasar empat aspek empati. Menurut Davis (dalam Nashori, 2008) Komponen kognitif terdiri dari Perspective Taking (PT) dan Fantacy (FS) dan komponen afektif meliputi Empathic Concern (EC) dan Personal Distress (PD). Masing-masing aspek empati kemudian dilatihkan dengan mengikuti alur kerja experiential learning, yaitu Tahap pengalaman konkret, refleksi, implementasi dan 
pengalaman nyata. Pengalaman-pengalaman nyata kemudian direfleksikan dengan mengkaji ulang apa yang telah dilakukannya tersebut. Pengalaman yang telah direfleksikan kemudian diatur kembali sehingga membentuk pengertian-pengertian baru atau konsepkonsep abstrak yang akan menjadi petunjuk bagi terciptanya pengalaman atau perilaku-perilaku baru. Persepsi, pengalaman, serta pemikiran baru inilah yang nantinya akan dilatih pengimplementasiannya dalam kehidupan sehari-hari siswa.

Experiential learning merupakan metode pembelajaran yang mendalam dimana siswa tidak hanya belajar secara kognitif, namun juga secara afektif, dan psikomotorik. Tahapan experiential learning yang mengubah cara pandang serta membentuk konsep pemikiran baru yang kemudian diaplikasikan oleh siswa, dapat menjadi upaya untuk menanamkan karakter empati secara mendalam. Keempat aspek empati yang semuanya dilatihkan juga dapat membentuk perilaku empati secara utuh. Kondisi ini memungkinkan empati dapat tertanan dengan baik pada siswa yang dilatihkan.

Dalam pelaksanaan paket bimbingan ini, terdapat beberapa kendala yang menjadi kekurangan pelaksanaan bimbingan ini, dan juga ada faktor pendukung yang mendukung pelaksanaan paket bimbingan ini. Adapun yang menjadi faktor pendukung adalah materi paket bimbingan yang menyasar empat aspek empati sehingga semua aspek empati dapat dilatihkan. Selain itu, pelaksanaan bimbingan yang berbasis experiential learning juga mempermudah penanaman perilaku empati yang mendalam pada diri siswa. Media bimbingan yang didesain menarik dan kegiatan bimbingan yang bervariasi, membuat siswa antusias dan tidak mudah bosan dalam mengikuti kegiatan bimbingan. Kebersediaan guru kelas dan sekolah untuk terbuka dan mempelajari hal baru yang bermanfaat bagi siswanya juga mempermudah penerapan paket bimbingan ini.

Sementara itu, kondisi guru kelas yang belum memiliki keterampilan melaksanakan bimbingan menjadi kendala tersendiri, oleh sebab itu perlu dilakukan pelatihan dan diskusi untuk membantu guru kelas dapat melaksanakan kegiatan bimbingan dengan baik. Murid sekolah dasar yang tidak terbiasa dan belum pernah mengikuti kegiatan bimbingan juga menjadi kendala, sehingga membutuhkan waktu yang cukup panjang untuk menyesuaikan kondisi kelas dan membiasakan siswa dengan kegiatan bimbingan.

Terlepas dari seluruh kelebihan dan kekurangan tersebut, paket bimbingan peningkatan empati berbasis experiential learning ini dapat diterapkan pada siswa kelas $\mathrm{V}$ untuk meningkatkan keterampilan empati yang dimilikinya. Paket bimbingan peningkatan empati ini teruji efektif untuk diterapkan pada siswa kelas V sekolah dasar. Hal ini dapat dilihat dari hasil uji pretest dan postest yang dilaksanakan pada kelompok kontrol dan kelompok eksperimen, dimana skor keterampilan empati siswa kelompok eksperimen setelah diterapkannya paket bimbingan peningkatan empati berbasis experiential learning menunjukkan skor yang lebih tinggi dibandingkan dengan siswa pada kelompok kontrol setelah mendapatkan pelatihan empati secara ekspositori. Prosedur pembelajaran dalam experiential learning yang terdiri dari empat tahapan, yaitu; tahapan pengalaman nyata, tahap observasi refleksi, tahap konseptualisasi, dan tahap implementasi mendukung meningkatnya keterampilan empati siswa. Dalam tahapan pengalaman konkret, peneliti mengajak siswa untuk menceritakan pengalaman nyata terkait keterampilan empati. Pengalaman tersebut kemudian direfleksikan secara individu. Dalam tahap refleksi seseorang akan berusaha memahami apa yang terjadi atau apa yang dialaminya. Tahap refleksi ini menjadi dasar konseptualisasi atau proses pemahaman prinsip-prinsip yang mendasari pengalaman yang dialami serta kemungkinan aplikasinya dalam situasi atau konteks yang lain (baru). Memasuki tahap implementasi, maka siswa memungkinkan untuk menerapkan konsep yang sudah dikuasai.

\section{PENUTUP}

\section{Simpulan}

Kesimpulan dari laporan kemajuan penelitian ini adalah penelitian telah dilaksanakan sesuai dengan rencana penelitian yang disusun. Dari hasil penelitian, didapatkan skor pretes dan postes skala empati dari kelompok eksperimen dan kelompok kontrol. Skor skala empati tersebut kemudian nantinya akan diolah dan dianalisis untuk dijadikan dasar penulisan laporan akhir mengenai keefektifan penerapan paket bimbingan peningkatan empati berbasis experiential learning bagi siswa sekolah dasar.

\section{DAFTAR RUJUKAN}

Andreasson, P. 2010. Emotional Empathy, Facial Reactions, and Facial Feedback. Acta Universitatis Upsaliensis. Digital Comprehensive Summaries of Uppsala Dissertations from the Faculty of Social Sciences 58. 52 pp. Uppsala. ISBN 978-91-5547840-7.

Andrianie, Santy. 2015. Pengembangan Paket Bimbingan Berbasis Experiential learning untuk Meningkatkan Empati Siswa Sekolah Dasar. Tesis Pascasarjana Jurusan Bimbingan dan Konseling Universitas Negeri Malang: Tidak diterbitkan. 
Borba, M. 2008. Building Moral Intelligence. San Fransisco : Josey-Bass.

Coroloso, Barbara. 2007. Stop Bullying (Memutus Mata Rantai Kekerasan Anak dari Prasekolah Hingga $S M U)$. Jakarta: Ikrar Mandiri Abadi

Davis, M.H. 1983. Measuring Individual Differences in Empathy. Journal of Personality and Social Psychology, 44, 113-126.

Goleman, D. 2007. Social Intelligence (terjemahan oleh Hariono S. Imam). Jakarta: PT. Gramedia Pustaka Utama.

Hoffman, M.L. 2000. Empathy and Moral Development: Implications for Caring and Justice. New York: Cambridge University Press.

http://www.m.liputan6.com/news/read/2191106/surveiicrw-84-anak-indonesia-alami-kekerasan-disekolah. Diunduh tanggal 15 April 2016.

Kartono, K . 2008. Kenakalan Remaja. Jakarta. Rajawali Pers.

Kolb, D. A. 1984. Experiential learning : Experience as The Source of Learning and Development. New Jersey : Prentice Hall, Inc.

Mardana, I.B. 2006. Implementasi Modul Eksperimen Sains Berbasis Kompetensi dengan Model Experiential learning dalam Upaya Meningkatkan Kualitas Pelaksanaan KBK dalam Pembelajaran Sains di SMP Negeri Sukasada. (Jurnal Pendidikan dan Pengajaran IKIP Negeri Singaraja, No.4. Hal 782-797)

Nashori, F. 2008. Psikologi Sosial Islam. Bandung: PT. Refika Aditama.

Saripah, I. 2010. Model Kognitif-Perilaku untuk Menanggulangi Perilaku Bullying (Model Konseling untuk Korban Bullying pada Siswa Sekolah Dasar). Disertasi Pasca Sarjana Jurusan Psikologi Pendidikan dan Bimbingan Universitas Pendidikan Indonesia Bandung: Tidak Diterbitkan.

Taufik. 2012. Empati Pendekatan Psikologi Sosial. Jakarta: Rajawali Pers. 